\title{
Divisia money and income in Indonesia: some results from error-correction models, 1981:1-1994:4
}

\begin{abstract}
The purpose of the present study is to provide alternatives to the monetary aggregates currently defined and published by Bank of Indonesia. The alternative monetary aggregate proposed is the Divisia aggregate which is an appropriate measurement for the monetary services of a country. In this paper we investigate the long-run relationship between income and Divisia aggregate together with its counterpart-the conventional simple-sum aggregate for the period 1981:1 to 1994:4. Using the cointegration and error-correction framework, our results indicate that there is potential role for the Divisia monetary aggregate as a useful intermediate indicator in the conduct of monetary policy in Indonesia.
\end{abstract}

Keyword: Divisia aggregate; Indonesia; Income; Monetary services 